\title{
RESTAURANT INNOVATIVENESS: A CASE STUDY OF VOJVODINA
}

\section{Snježana Gagić*}

University of Business Studies, Faculty of Tourism and Hotel Management, 23a Jovana Dučića Street, Banja Luka, Bosnia and Herzegovina

\begin{abstract}
:
It is of vital importance to continuously work on the improvement and identification of significant factors to ensure and sustain the desired level of quality. The paper aims to analyze the innovativeness level of restaurants in Vojvodina in view of the fact that it keeps their portfolio competitive and thereby achieves a long-term competitive advantage. The innovativeness level was defined on the basis of the instrument designed for measuring innovation in the field of products and services, marketing, processes and socially responsible behavior. In order to determine the level of innovativeness, it was necessary to first determine the percentage of innovativeness based on the number of innovations introduced by the restaurants in all of the four study areas.

The results show that a significant number of restaurants pays attention to innovations in order to become more appealing to guests and increase their profitability. On the other hand, more than half of the observed restaurants have a very low or low degree of innovation, which indicates that we still do not pay enough attention to innovations and advancement of their business implementation.
\end{abstract}

\section{INTRODUCTION}

The main characteristics of everyday life, work and earnings are reflected in increasingly rapid and frequent changes. Accordingly, innovations appear as a source of change which is necessary for successful business activities. Those who are not innovative shall lose their market position and deteriorate. Should restaurateurs consider innovations a competitive weapon, they will have to become more innovative than the competition, make changes and accelerate their implementation, create an innovative atmosphere, and make full use of their employee creativity (Cox et al., 2011).

Innovations simplify all changes introduced by restaurateurs, regardless of the fact that they are absolute novelties, reproduced by the competitors or adapted products or services (Linton, 2009).

Nowadays, it can be said that innovating, i.e. introduction and implementation of new ideas in the restaurant business, represents the basis for creating and sustaining the competitive advantage (Nicolau \& Santa-María, 2013). Innovations appear as the main success factor as they improve the 
quality of products, increase the overall efficiency, reduce costs, meet the needs of customers, increase sales and profit, and contribute to increasing the market share and differentiating from competition (Su, 2011).

The paper aims to show innovation in terms of offer, marketing, processes and socially responsible behavior. The majority of dishes becomes less attractive over time and gets removed from the menu, so the restaurateurs are forced to replace them with the new ones. In such circumstances, innovations appear as an obligatory managerial task, crucial for the restaurants' prosperity (Ottenbacher and Harrington, 2009), despite high risk in terms of new dish placement (Manning et al., 1995).

Information on the old craftsmen's service quality was transmitted orally once, while nowadays this kind of information is transferred faster due to modern information technologies. In order to retain the present guests and attract new ones, restaurateurs use new media, promotion techniques, and latest methods of distribution and sales channels. The Internet has become a necessary means for following the global trends in almost every business domain and has proven to be the most efficient media in communicating with target groups in the catering business. Today, guests create a kind of marketing that cannot be completely controlled, by posting their impressions publicly, either positive or negative. With their presence on social media, restaurateurs have market access, learn about the consumers' trends and communicate with guests (SeongSeop, KuoChing \& TaeHong, 2013). Adopting new processes is important for those restaurateurs who want to stay competitive by raising the quality level of products and services and hire professional staff (sommeliers,flambers, butchers, barmen) or home delivering and making online food ordering possible (Gagić, 2014).

An innovative attitude in modern business cannot disregard the issue of corporate social responsibility (Chan, 2011). Introducing such innovations into the organizational culture contributes not only to guest loyalty (Martínez and Rodríguez del Bosque, 2013), but also to the restaurant's image and costs saving (Schubert et al., 2010).

That being said, the paper attempts to examine the innovativeness level of restaurants in Vojvodina with the aim to identify business segments that need to be improved in order to provide optimum quality of hospitality products and services and achieve most favorable business results. The manuscript aims to determine whether and to what extent restaurateurs follow the activity trends, as well as to give suggestions for enhancing the overall business performances through implementation of such innovative strategies.

\section{LITERATURE REVIEW}

\section{INNOVATION IN RESTAURANT BUSINESS}

Innovation is an important aspect of contemporary business. Rapid changes in guests' preferences and expectations significantly affect the restaurant industry.

Within the catering context, innovations are referred to as "an idea, practice, process or product which puts into practice ideas that solve problems and are perceived as new by the consumers" (Ottenbacher \& Gnoth, 2005). Innovations are also defined as all those novelties that restaurateurs introduce regardless of whether they are absolute novelties, reproduced by the competitors or adapted products or services (Linton, 2009). The surveys that placed special emphasis on innovation in the catering industry have shown that upon implementing innovations, restaurants have become more appealing to guests, which has a considerable bearing on the overall profitability (Ottenbacher \& Gnoth, 2005).

\section{Menu innovation}

Catering managers should make their menus more innovative so as to be able to respond properly to modern gastronomic trends and create the offer that is in accordance with the guests' cur- 
rent demands. Restaurateurs should broaden the offer of dishes made with ingredients perceived by guests as healthy, such as whole grain cereals, organically grown food, low-energy and low-fat and gluten-free food. The healthy diet trend and consumers' knowledge about the connections between nutrition and health have led to an increase in consumption of reduced-fat content products, the so-called light products (Cerjak et al., 2007).

One of the trends is also the organic food offer served in modern restaurants with the aim of making profit and offering new gastronomic experiences (Poulston \& Yiu, 2011).

Although the Restaurant Hospitality magazine has published that there has been an increasing need for vegetarian dishes (Rowe, 2010), it is still difficult to find an adequate selection of such dishes on the menu in numerous restaurants. Despite the fact that this is the leading trend in the catering business, a vast number of restaurateurs still do not follow it (Lanou, 2007). The majority of chefs have been reluctant to vegetarian dishes considering them uninspiring and difficult to prepare.

Over the past few years, whole grain cereals have been a really high demand aliment. $64,8 \%$ of respondents in the Republic of Serbia believe that fast food restaurants should consider upgrading their offer by introducing wholegrain food, which suggests an increase of guests' awareness about the importance of a healthy diet, but also the impact of trends that give priority to whole grain cereals over refined grains (Gagić et al., 2012).

Gluten, the storage protein found in wheat, rye and oat seed as in their hybrid varieties, represents a diet disturbance for certain percentage of guests. In this business segment, an innovative offer means gluten-free gastronomic offer. Gluten intolerance is often a limiting factor for those who want to dine out. In a Canadian survey, out of 2681 participants with gluten intolerance, $54 \%$ have stated that they avoid eating at restaurants. When asked about the factor they believe would improve the quality of life, almost half of them (49\%) said that it would be the gluten-free choice of dishes offered by the restaurants (Rashid et al., 2005).

A selection of sweets for diabetics and dieters is the next step in the creation of an innovative choice of desserts. Sorbitol, mannitol and xylitol can be used as a substitute for fructose (Gagić et al., 2011).

\section{Marketing innovations}

In order to achieve favourable business results, current business conditions require not only a quality gastronomic offer and professional service, but also the constant and targeted promotion with the aim of making the potential guests conversant with the offer, while reminding the regular ones of the provided quality and informing them of new events related to restaurants' activity and offer (Kotler et al., 2003). As regards meeting the guests' needs and wishes, the marketing concept has undergone significant evolutionary changes over the last few years, from traditional marketing to the one based on the relationship with clients (Salai et al., 2007).

Logo design and the overall visual identity is a very important item for image building and brand positioning in the consumers' mindset. The brand must motivate, move to action, evoke emotions and associations and create trust (Abimbola \& Vallaster, 2007). A well-designed web page can help restaurateurs to develop brands and attract new clients (Hwang et al., 2011).

A lot of restaurateurs have started using social media with the purpose of communicating with guests and creating unique brand pages (e.g. fan pages) used to connect with potential customers and establish contacts with the current ones (Lee et al., 2012). In May 2012, McDonalds had 19.5 million likes on its Facebook fan page, Chick-fil-A had 5 million, Wendy's had 2.3 million and Outback Steakhouse had 2 million likes (Preece et al., 2004).

SMS texting and electronic mail services are the most popular ways for establishing direct communication with clients. The customers will decide to leave their personal data and give permission 
to be contacted in case they can somehow benefit from that. That's why the most efficient way of customers' data collection is through forming a loyalty club that would provide its members with certain discounts (Jang \& Mattila, 2005).

\section{Process innovations}

Process innovations mean professional staff engagement (sommeliers, flambers, barmen etc.), home delivery and other activities that contribute to the improvement of restaurant's performances. Sommeliers increase the sales of wine thanks to their knowledge of food and wine pairing combined with suggestive selling techniques (Manske \& Cordua, 2005). Researchers have shown that hiring a sommelier can increase beverage revenue by $15-25 \%$ (Robinson et al., 2005).

Since dining at home is becoming more and more popular and modern technologies are improving the delivery process, it is expected that the profit made by restaurateurs from the food delivery system will increasingly grow in the next period. According to the NPD market analysis, a group in the survey A Look into the Future of Eating, it is foreseen that the number of restaurant meals eaten at home will increase by $20 \%$ in the next 10 years.

\section{Innovations related to socially responsible behavior}

Corporate Social Responsibility represents a concept according to which commercial entities that adopt it consciously and voluntarily transcend their making and distribution profit primary function and create positive effects on their work, social and natural environment (Kramo \& Babić-Hodović, 2007).

Investing in staff training and improvement is seen as an effective practice of corporate social responsibility, thanks to which the existing results in the workplace are maintained or enhanced. Socially responsible activities intended for employees consist of monitoring and improving their satisfaction with everyday work conditions, position and interpersonal relations on both horizontal and vertical level (Čerović, 2013). Offering financial support to employees for the preferred sports activities (co-financing or a total coverage of the costs), organizing socialization activities among the staff such as trips, providing scholarships to support employee education or their children's education, babysitting service at the workplace, bonus payments, granting the thirteenth month pay to all employees or the annual bonus, are just some of the activities that can demonstrate respect to an employee and contribute to his loyalty (Vlahović, 2007).

Social responsibility also implies responsible behavior towards guests. The existence of work regulations for employees, who are in direct contact with the guests for a good standardized treatment, shows responsibility towards them. By applying standards in providing services, there is an increase of process efficiency and effectiveness and improvement of product and service quality. This kind of attitude, at the same time, meets the needs of service customers and contributes to increasing their satisfaction (Pirija, 2003). An indolent and careless approach to complaints will result in the loss of clients and switch to the competition. Complaints and formal appeals must be solved fast and efficiently (Hsu, 2013).

The Corporate Social Responsibility concept encompasses and extends to the integration of the company into its business environment. Companies contribute to local communities not only by securing jobs and paying taxes, but also by supporting employee prequalification and additional qualifications, sponsoring local sports clubs, cultural and other events, donating goods, money or old equipment, providing scholarships for talented students, organizing voluntary blood donation activities etc. (Atanacković, 2011).

Socially responsible behavior also implies adopting an ecological approach towards conducting business (Gagić et al., 2013). There are a lot of 
"green" practices that can be implemented in restaurants, including energy efficiency, water savings, recycling, use of local groceries and pollution prevention (DiPietro et al., 2013).

\section{METODOLOGY}

\section{Sampling}

The sample included thirty fine dining and casual dining restaurants selected in 19 towns in Vojvodina. The information was obtained through an interview with restaurant managers. Restaurants were chosen based on the following criteria:

- business duration (minimum three years) and

- restaurant capacity (minimum 50 seats).

\section{Research period}

Research was conducted during the period from February 10 to May 18, 2014.

\section{Survey sampling method}

A voluntary sample is made up of people who visited the observed restaurants.

\section{Questionnaire design}

The innovation level was defined on the basis of the instrument designed for measuring innovation in the field of products and services, marketing, processes and socially responsible behavior.

Products and services innovativeness involved: offer of vegetarian dishes, gluten-free dishes, wholewheat bakery products, dishes for diabetics, children's menu, organically grown food, marking allergens, menu changes (more than twice a year), different portion sizes, energy value of menu items, menu translation, wines from autochthonous grapes, free wireless network, as well as marking local and national dishes on the menu. Marketing innovativeness involved: marketing plan, data- base, logo, web page, social networks pages and QR code. Process innovativeness involved: engagement of sommeliers, flambers, food delivery and the possibility of online ordering.

Corporate social responsibility innovativeness involved: implementing some quality standards or systems (ISO, HACCP), participation in humanitarian actions, financing of cultural or sports event, young people training, use of local products, waste separation, waste recycling, energy efficient appliances and equipment, financing employee training and stimulating employee motivation.

\section{Data analysis}

In order to determine the level of innovativeness, the percentage of innovativeness was first determined based on the number of innovations that restaurants have introduced in all of the four study areas. Subsequently, the calculation of innovativeness has been made using proportion. After the obtained data on the innovativeness percentage, the classification of restaurants was made and the level of innovativeness was determined according to Table 1.

\begin{tabular}{cc}
\hline $\begin{array}{c}\text { Innovativeness } \\
\text { percentage }\end{array}$ & $\begin{array}{c}\text { Innovativeness } \\
\text { level }\end{array}$ \\
\hline $0-30 \%$ & Very low \\
\hline $30-50 \%$ & Low \\
\hline $50-70 \%$ & Medium \\
\hline $70-90 \%$ & High \\
\hline $90-100 \%$ & Very high \\
\hline
\end{tabular}

Table 1. Classification of restaurants according to innovativeness level

Upon receiving the listed data, the statistical analysis was done by calculating certain statistical features and conducting statistical tests. 


\section{Hypothesis and assumption}

$\mathrm{H}_{1}$ : None of the restaurants has the maximum number of innovations.

$\mathrm{H}_{2}$ : There will be more restaurants that are not innovative.

\section{RESULTS AND DISCUSSION}

The innovativeness of the restaurants in Vojvodina has been determined based on the number of implemented innovations in relation to the total number of innovative activities being offered.

Chart 1 clearly shows that innovativeness of the restaurants in Vojvodina is very various. It can also be seen that none of the observed restaurants has the maximum number of innovations (34), whereas there are some restaurants with less than ten innovations. Those are the restaurants that implemented up to $30 \%$ of innovative activities given and were listed among those restaurants with a very low innovativeness level.
Out of the total number of considered restaurants (30 restaurants), only two of them have a very low level of innovativeness (Table 2) and are represented by $7 \%$ of the analyzed group of restaurants (Chart 1).

Chart 2 shows that only a few restaurants have labeled allergens in the menu ( 1 of 30 ), offer dishes made from organically grown food (3 of 30), have dishes for diabetics ( 5 of 30 restaurants), while there is no restaurant that has the energy value of menu items.

It is well-known that the whole-wheat bakery products have become part of the restaurant offer in Vojvodina- only five restaurants don't have it. Products and services innovations implemented in many restaurants are menu changes (more than twice a year) (24 restaurants), different portion size offer (27 restaurants), menu translation (25 restaurants), wine offer from autochthonous grapes (29 restaurants), as well as free wireless network (26 restaurants).

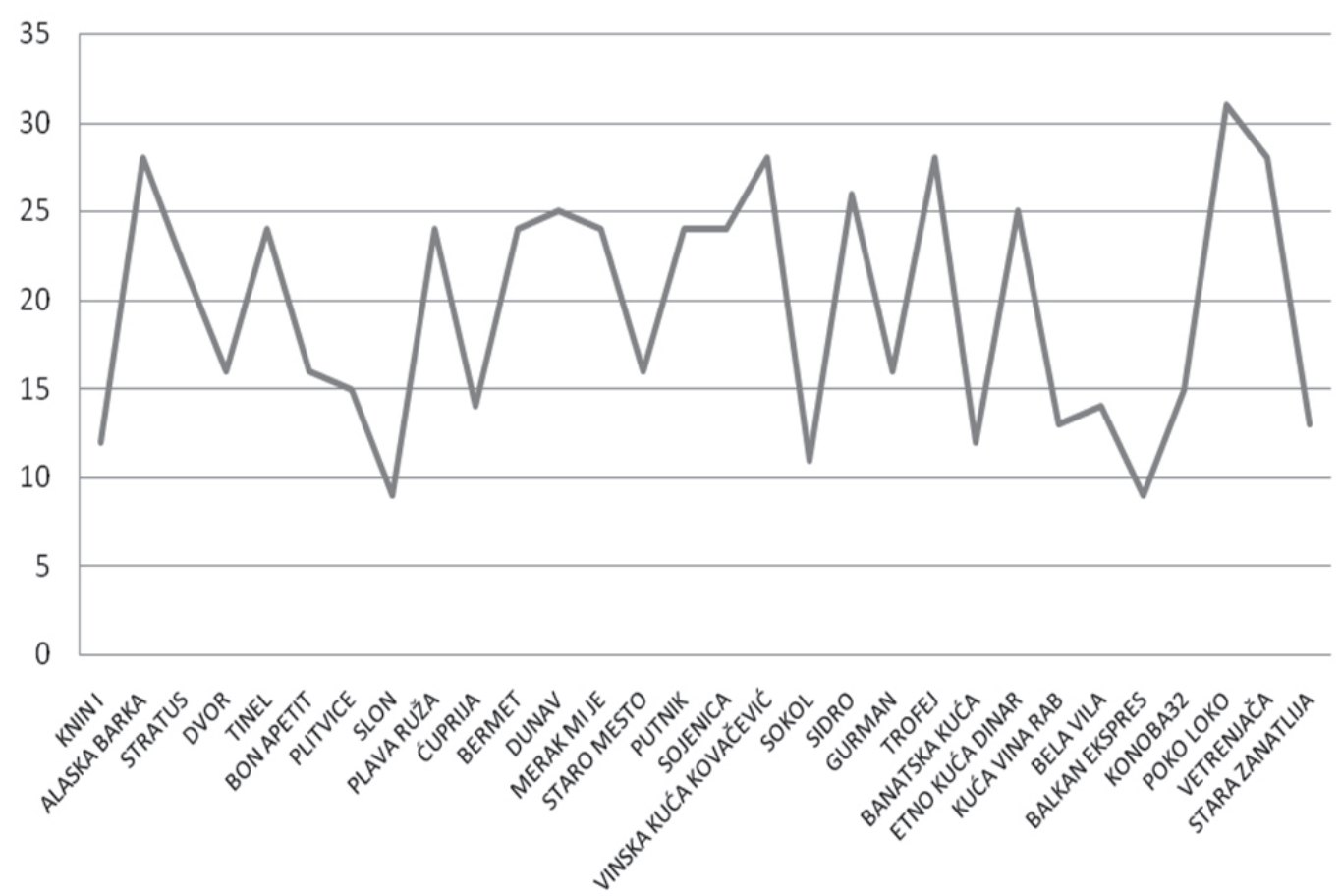


Marking local and national dishes on the menu

Free wireless network

Wines from autochthonous grapes

Menu translation

Energy value of menu items

Different portion sizes

Menu changes (more than twice a year)

Organically grown food

Children's menu

Dishes for diabetics

Whole-wheat bakery products

Marking allergens

Gluten-free dishes

Offer of vegetarian dishes

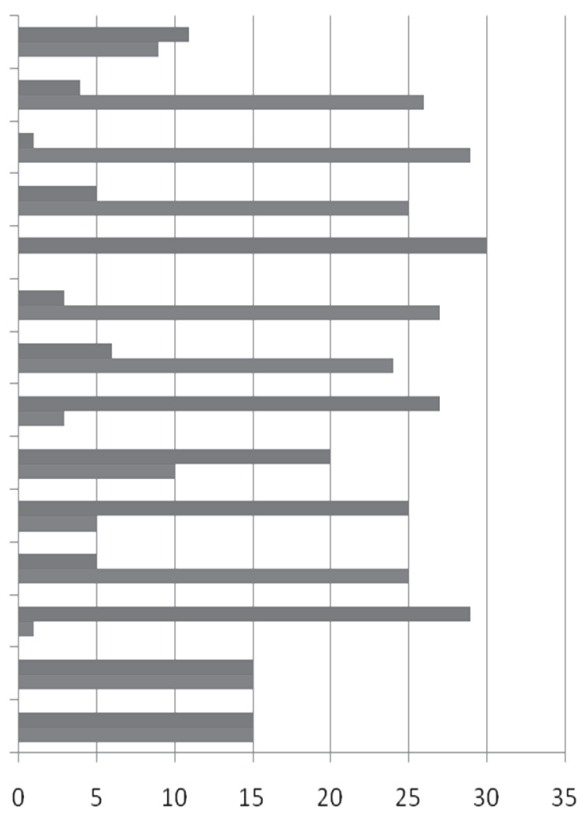

No - Yes

\section{Chart 2. Innovation in the field of products and services}

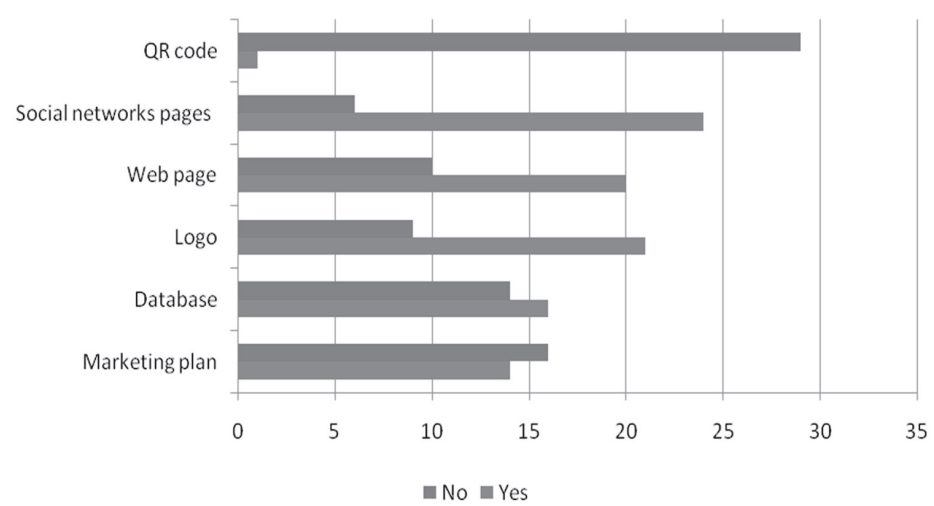

\section{Chart 3. Marketing innovations}

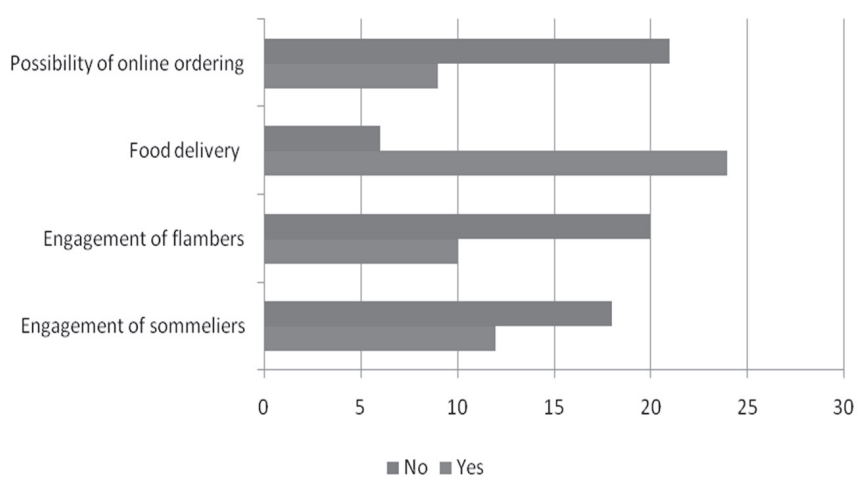


Although planning of restaurant marketing is the key for booming business, less than half of restaurants have a marketing plan (14 restaurants). Almost half of restaurants don't have the database (14). Majority of them has a company logo (21 restaurant), web page (20) and social network pages (24). There are a lot of places to incorporate QR codes into restaurant menu (daily specials, nutritional information, ingredient, chef recommendation etc.), but that fact is not recognized among Vojvodina's restaurateurs. Only one of them has a QR code.

Engagement of high profile professional staff such as sommeliers and flambers is a business strategy which can be observed in only one third of the observed restaurants. Majority of restaurants have food delivery option (24 restaurants), while just nine of them have the possibility of online ordering.

Somewhat more than half of restaurants (16) have implemented some quality standards or systems (ISO, HACCP). Majority of restaurants have participated in humanitarian actions (24), youth training (26), use of local products (28), recycling of some kind of waste (30), employee motivation (28) as well as funding of cultural or sports events (21).
They are inactive in waste sorting (only 12 of them separate it). These results also support the claim that financing employee training is not that popular in Serbia, as only 10 out of 30 restaurants pay for such trainings.

\begin{tabular}{cccc}
\hline $\begin{array}{c}\text { Innovative- } \\
\text { ness level }\end{array}$ & $\begin{array}{c}\text { Number of } \\
\text { restaurants }\end{array}$ & $\begin{array}{c}\text { Cumulative } \\
\text { number of } \\
\text { restaurants }\end{array}$ & $\begin{array}{c}\text { Cumulative } \\
\text { structure } \\
(\%)\end{array}$ \\
\hline $0-30$ & 2 & 2 & 7 \\
\hline $30-50$ & 14 & 16 & 54 \\
\hline $50-70$ & 1 & 17 & 57 \\
\hline $70-90$ & 12 & 29 & 97 \\
\hline $90-100$ & 1 & 30 & 100 \\
\hline Total & 30 & & \\
\hline
\end{tabular}

Table 2. The structure of restaurants based on the innovativeness level

A low level of innovativeness is reflected by those restaurateurs who implemented $30 \%$ to $50 \%$ of innovative activities offered. That is the case with fourteen restaurants out of the total number and they are represented by $47 \%$, which is the

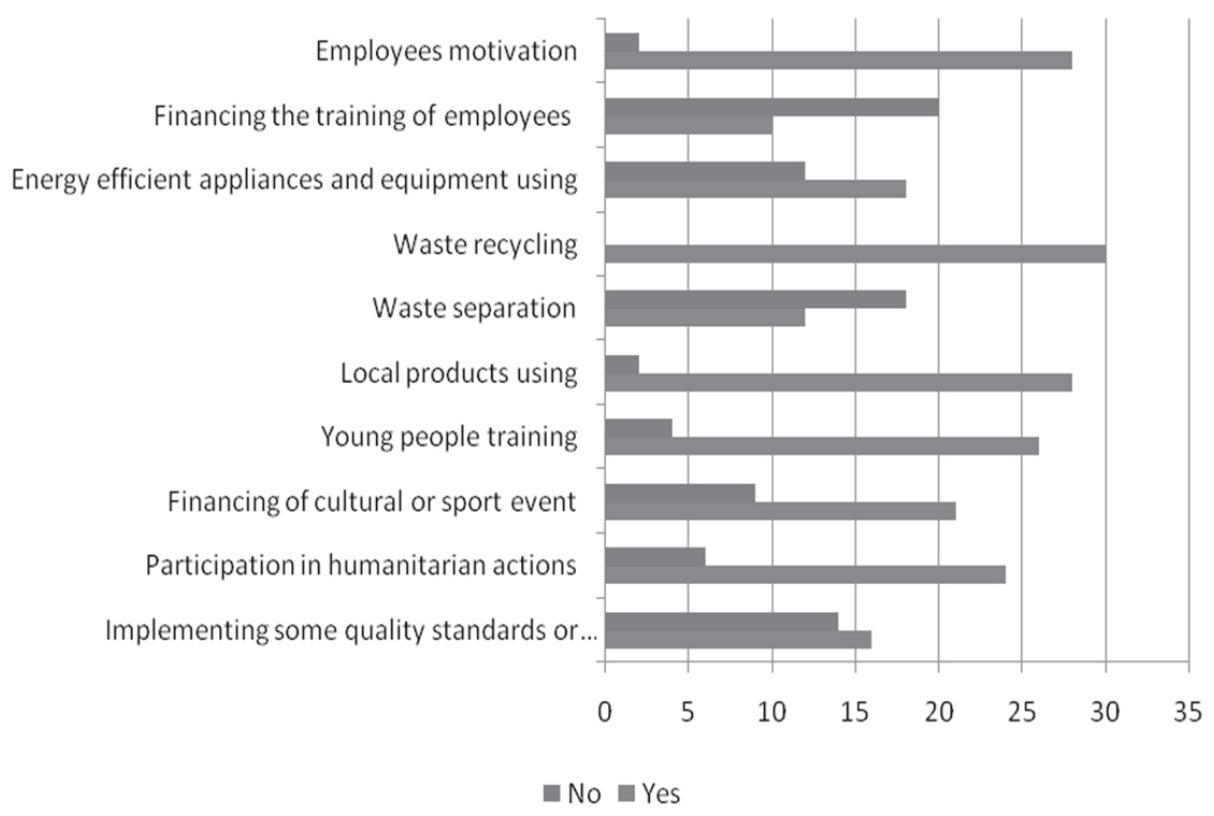


highest value among the observed restaurants.

The restaurants that implemented $50 \%-70 \%$ of the given innovative activities are considered to have a medium level of innovativeness. Only one restaurant among those analyzed has a medium level of innovativeness and is represented by $3 \%$.

A high innovativeness level is considered to be $70 \%$ to $90 \%$ of the innovative activities offered. It is the case of 12 observed restaurants, i.e. $40 \%$ of the total number of the observed restaurants. The implementation of $90 \%-100 \%$ of the given innovative activities is considered a very high level of innovativeness. Among the analyzed restaurants, only one has a very high level of innovativeness, i.e. it represents $3 \%$ of the structure.

Based on the considered structure of innovativeness level, it is noticeable that more than half of the observed restaurants have a very low and low level of innovativeness, i.e. are represented by $54 \%$ (Table 2). Thirteen restaurants have a high or very high level of innovativeness (43\%) among the group of restaurants considered in the analysis. All of this indicates that one significant part of restaurants pays attention to innovations in the catering industry, with the purpose of becoming more appealing to guests and increasing their profitability. On the other hand, more than half of the analyzed restaurants have a very low or low level of innovative- ness, which indicates that they are still not paying enough attention to innovations and improvement of their business through implementation.

\begin{tabular}{lc}
\hline $\begin{array}{c}\text { Statistic } \\
\text { indicators }\end{array}$ & $\begin{array}{c}\text { Indicators' value } \\
(\%)\end{array}$ \\
\hline Average value & 56.67 \\
\hline Median value & 47.06 \\
\hline Minimal value & 26.47 \\
\hline Maximum value & 91.18 \\
\hline Variation coefficient & 34.51 \\
\hline
\end{tabular}

Table 3. Main statistical indicators of innovativeness level

The average value of the analyzed group is 56 , i.e. $67 \%$, which represents a medium level of innovativeness. The defined median value of $47.06 \%$ indicates that fifteen out of thirty restaurants have a lower level of innovativeness, while the remaining fifteen exceed the median value. As regards the innovativeness level, it can be said that the observed group of restaurants is rather polarized, i.e. both low and high levels of innovativeness are equally represented. The evaluation of the expected level of innovativeness within the catering sector in

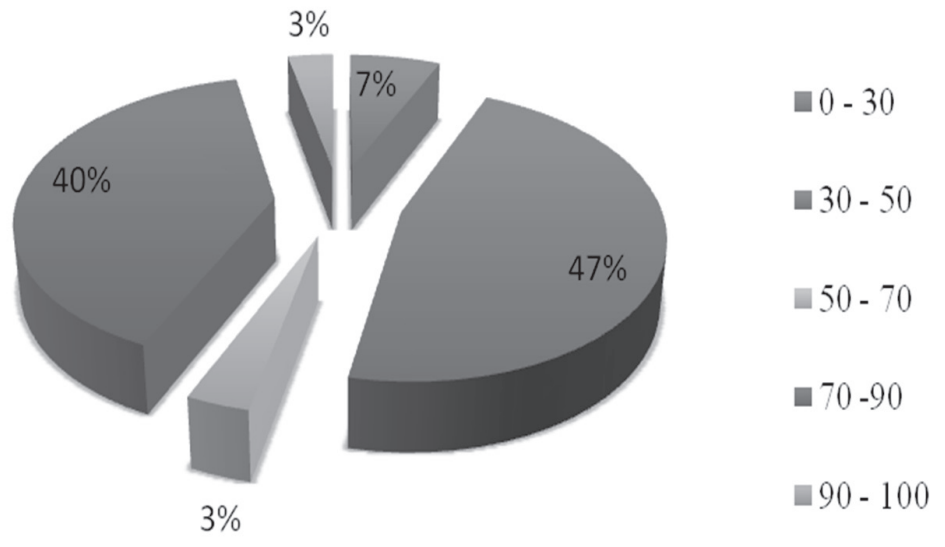

Chart 6. The structure of restaurants based on the innovativeness level 
Vojvodina, obtained on the basis of the observed sample of thirty restaurants, may be in favor of this deduction. There is a rather strong possibility (95\%) that the level of innovativeness related to the catering in Vojvodina should be expected to range between $49.36 \%$ and $63.97 \%$, which indicates a medium level of innovativeness.

\section{CONCLUSION}

None of the observed restaurants has the maximum number of innovations as assumed $\left(\mathrm{H}_{1}\right)$, whereas there are some restaurants that have less than ten innovations. More than half of the observed restaurants have a very low or low level of innovativeness, which indicates that they are still not paying enough attention to innovations and business enhancement by implementing them.

As regards the level of innovativeness, it could be said that the analyzed group of restaurants is polarized i.e., both low and high levels of innovativeness are equally represented, which confirms that $\mathrm{H}_{2}$ that there will be more restaurants that are not innovative cannot be considered valid.

Restaurateurs should work on changing the offer, creating new gastronomic products that will replace the old ones once the guests stop ordering them. Innovations related to this business segment are considered essential for the prosperity and business enhancement, evolving from a strategic option to a mandatory management task. The implementation of incremental innovations such as the offer of vegetarian dishes, gluten-free dishes, whole grain bread and dough, sweets for diabetics, organically grown groceries will please those guests whose dietary habits have been changed and determined by the current gastronomic trends.

It is well-known that restaurants enhance their image as innovative organizations that follow guests' requests by introducing such innovations. Since restaurateurs are not confined by regulations related to the prescribed standards, the size of the portions may vary from one restaurant to another. Different-sized portions are seen as a good way to please the customers who are not willing to pay for what they do not manage to eat, but also to avoid food wasting. Creating a special menu for children is considered a useful way to attract families with children. If restaurants are focused on such kind of customers as their target group, they must pay attention not only to the creation and design of the offer intended for the children, but also to the ways of animating children. Dishes of interesting shapes and colours, cutlery with children's favourite cartoon characters' stickers, a corner specially equipped with picture books and drawing tables are just some of the ways to win over this type of guests. Highlighting local and national dishes on the menu is considered to be a novelty that will please those guests that are searching for an authentic national cultural experience, and, at the same time, it will promote and popularize the national gastronomy. The same effect will be achieved through the offer of autochthonous wines, while the gastronomic offer will be enhanced by an adequate selection of this beverage.

Considering the fact that more and more people use the Internet on a daily basis and the growing need to be online, it is necessary to provide wireless internet access. There is an increasing number of guests who possess smart phones or carry their laptops with them. Hence, the presence of wireless internet access represents an important factor in choosing the place to eat at. The restaurateurs who do not recognize this need may risk losing the guests who wish to be online. In order to achieve satisfactory business results, quality food and beverages are no longer sufficient, as it is also necessary that the restaurateurs use new forms of media, promotional techniques, and new distribution methods and sales channels to retain the present quests and attract new ones. In order to perform that successfully, it is necessary to have a well-defined action plan and web site, working on brand making and gaining visibility on social networks. The Internet has proved to be the most 
efficient media for communicating with clients. What is typical nowadays is the possibility for every guest to participate in the restaurant marketing activities: by leaning comments on online portals and social networks, the guest creates the restaurant image and influences potential guests. The presence on social networks enables restaurateurs to learn about consumer trends and communicate with clients, which allows them to determine what is that they want and driven by that they are able to create their own business policy.

In order to provide a successful service delivery, it is necessary to engage high profile professional staff such as sommeliers and flambers. It has been demonstrated that hiring a sommelier leads to greater profit, staff training should be considered as an investment, not an expense. Flambéed dishes are more expensive than those cooked regularly, so that even in this case the income is clear. There are also other effects achieved by such innovation process, e.g. creating attraction for the guests, improving the flavor of the dish, highlighting the staff capability and competence etc. Selling mixed drinks can also be listed as a successful business activity since mixed drinks are much more expensive than regular drinks. Home delivery is a way for the restaurant to sell its products outside the workplace, which is considered a good way of using the existing resources. In this process, it is important to establish a quality delivery system, i.e. the restaurateur should provide an adequate packaging that will maintain the quality of the dish until it reaches the client. In order to successfully complete this process, it is essential to pay attention to reliability, accuracy, taste, texture and temperature of the final product.

Nowadays, companies are expected to go beyond their personal interests and consider themselves, first of all, as part of the society they belong to. Socially responsible behaviour such as providing financial support to employees for the preferred sports activities (co-financing or total costs coverage), participating in charity actions, financing cultural events, hiring young staff for practice training, using local products for business purposes, separating and recycling waste, using energy-efficient devices and equipment, financing employee training and applying various employee motivation principles, helps the restaurateurs to demonstrate their ethics and responsibility towards their business environment, clients and employees.

\section{REFERENCES}

Abimbola, T., \& Vallaster, C. (2007). Brand, organisational identity and reputation in SMEs: An overview. Qualitative Market Research: An International Journal, 10(4), 341-348.

Atanacković, U. (2011). Društveno odgovorno poslovanje kao savremeni koncept biznisa. Škola biznisa, 1(2011), 143-148. In Serbian.

Cerjak, M., Rupčić, I., Tomić, M., \& Zrakić, M. (2007). Consumer bahaviour regarding "light" food products on the Zagreb market. Journal of Central European Agriculture, 8(2), 257-268.

Čerović, S. (2013). Upravljanje ljudskim resursima $u$ hotelijerstvu. Beograd: Univerzitet Singidunum. In Serbian.

Chan, E.S.W. (2011). Implementing environmental management systems in small andmedium-sized hotels: obstacles. Journal of Hospitality and Tourism Research, 35(1), 3-23. doi:10.1177/1096348010370857.

Cox, R., Davidson, M., \& Wilkins, H. (2011). Exploring Innovation Strategies that affect business performance in restaurants. In: International conference on hospitality \& leisure applied research (I-CHLAR 2011): Balancing Art, Innovation \& Performance. Retrieved December 5, 2015, from http://hdl.handle.net/10072/47046

DiPietro, R., Cao, Y., \& Partlow, C. (2013). Green Practices in Upscale Foodservice Operations: Customer Perceptions and Purchase Intentions. International Journal of Contemporary Hospitality Management, 25(5), 779-796. doi:10.1108/IJCHM-May-2012-0082

Gagić, S., Psodorov, D., \& Ostojić, G. (2011). Principi inovativne gastronomske ponude. Zbornik radova Departmana za geografiju, turizam i hotelijerstvo, br. 40, 188-197. Beograd: Prirodno matematički fakultet. In Serbian. 
Gagić, S. (2014). Evaluacija efekata inovativnosti u funkciji unapređenja kvaliteta i lojalnosti gostiju $u$ restoraterstvu Vojvodine. Doktorska disertacija, Univerzitet u Novom Sadu, Prirodno-matematički fakultet, Departman za geografiju, turizam i hotelijerstvo. In Serbian.

Gagić, S., Jovičić, A., Tešanović, D., \& Popov-Raljić, J. (2012). The structure and development of the offer of fast food restaurant chains in Serbia. Contemporary tourism: wishes and opportunities, Belgrade, March 22-24, 2012 (pp. 559-659).

Gagić, S., Jovičić, A., \& Erdeji, I. (2013). Green technologies in the hospitality industry. In: Environmental protection of urban and suburban settlements : proceedings / XVII International Eco-Conference, 2528th September 2013 (pp.515-523). Novi Sad: Album.

Hsu, J.L. (2013). Effects of interactive marketing on customer satisfaction in catering industry. Actual Problems of Economics/Aktual'ni Problemi Ekonomiki, 141(3), 424-431.

Hwang, J. Yoon, Y., \& Park, N. (2011). Structural effects of cognitive and affective reponses to web advertisements, website and brand attitudes, and purchase intentions: The case of casual-dining restaurants. International Journal of Hospitality Management, 30(4), 897-907. doi:10.1016/j.ijhm.2011.01.011

Jang, D., \& Mattila, A.S. (2005). An examination of restaurant loyalty programs: what kinds of rewards do customers prefer? International Journal of Contemporary Hospitality Management, 17(5), 402-408. doi:10.1108/09596110510604823

Kotler, P., Bowen, J.T., \& Makens, J.C. (2003). Marketing for hospitality and tourism. Boston: Pearson International Edition.

Kramo, A., \& Babić-Hodović, V. (2007). Koncept društvene odgovornosti, mogućnost primjene $i$ ograničenja. Zbornik radova Ekonomskog fakulteta u Sarajevu, 27, 389-411. In Bosnian.

Lanou, A.J. (2007). Demand for vegetarian dining continues to grow. Nation's Restaurant News, 41(26), 44.

Lee, W., Xiong, L., \& Hu, C. (2012). The effect of Facebook users' arousal and valence on intention to go to the festival: Applying an extension of the technology acceptance model. International Journal of Hospitality Management, 31(3), 819-827. doi:10.1016/j. ijhm.2011.09.018.

Linton, J.D. (2009). De-babelizing the language of innovation. Technovation, 29(11), 729-737. doi:10.1016/j. technovation.2009.04.006
Manning, K.C., Bearden, W.O., \& Madden, T.J. (1995). Consumer innovativeness and the adoption process. Journal of Consumer Psychology, 4(4), 329-345. doi:10.1207/s15327663jcp0404_02

Manske, M., \& Cordua, G. (2005). Understanding the sommelier effect. International Journal of Contemporary Hospitality Management, 17(7), 569-676. doi:10.1108/09596110510620645

Martínez, P., \& Rodríguez del Bosque, I. (2013). CSR and customer loyalty: The roles of trust, customer identification with the company and satisfaction. International Journal of Hospitality Management, 35, 89-99. doi:10.1016/j.ijhm.2013.05.009

Nicolau, J.L., \& Santa-María, M.J. (2013). The effect of innovation on hotel market value. International Journal of Hospitality Management, 32, 71-79. doi:10.1016/j.ijhm.2012.04.005

Ottenbacher, M., \& Gnoth, J. (2005). How to develop successful hospitality innovation. Cornell Hotel and Restaurant Administration Quarterly, 46(2), 205222. doi: $10.1177 / 0010880404271097$

Ottenbacher, M., \& Harrington, R. (2009). The product innovation process of quick-service restaurant chains. International Journal of Contemporary Hospitality Management, 21(5), 523-541. doi:10.1108/09596110910967782

Pirija, D. (2003). Standardi u turističkom ugostiteljstvu. Šibenik: Visoka škola za turizam. In Croatian.

Poulston, J., \& Yiu, A.Y.K. (2011). Profit or principles: Why do restaurants serve organic food? International Journal of Hospitality Management, 30(1), 184-191. doi:10.1016/j.ijhm.2010.04.004

Preece, J., Nonnecke, B., \& Andrews, D. (2004). The top five reasons for lurking: Improving community experiences for everyone. Computers in Human Behavior, 20(2), 201-223.

Rashid, M., Cranney, A., Zarkadas, M., Graham, I.D., Switzer, C., Case, S., \& Butzner, J.D. (2005). Celiac disease: evaluation of the diagnosis and dietary compliance in Canadian children. Pediatrics, 116(6), 754-759. doi:10.1542/peds.2005-0904

Robinson, C., Abbott, J.A., \& Shoemaker, S. (2005). Recreating cheers: an analysis of relationship marketing as an effective marketing technique for quickservice restaurants. International Journal of Contemporary Hospitality Management, 17(7), 590-599. doi:10.1108/09596110510620663

Rowe, M. (2010). Five trends you can't ignore. Restaurant Hospitality, 94(7), 22-28. 
Salai, S., Hegediš, I., \& Grubor, A. (2007). Marketing komuniciranje. Subotica: Ekonomski fakultet. In Serbian.

Schubert, F., Kandampully, J., Solnet, D., \& Kralj, A. (2010). Exploring consumer perceptions of green restaurants in the US. Tourism and Hospitality Research, 10(4), 286-300. doi:10.1057/thr.2010.17

Seongseop, K., Kuo-Ching, W., \& Tae Hong, A. (2013). Which endorser and content are most influential in Korean restaurant promotions? International Journal of Hospitality Management, 33, 208-218. doi:10.1016/j.ijhm.2012.08.005
Su, C.S. (2011). The role of service innovation and customer experience in ethnic restaurants. The Service Industries Journal, 31(3), 425-440. doi:10.1080/02642060902829302

Vlahović, S. (2007). Upravljanje ljudskim resursima $i$ njegova primena u turizmu i hotelijerstvu. Hotelsko poslovanje: materijal za seminar (pp. 85-105). Beograd: Univerzitet Singidunum. In Serbian.

\section{INOVACIJE U RESTORATERSTVU: STUDIJA SLUČAJA ZA VOJVODINU}

\section{Rezime:}

Kontinuiran rad na prepoznavanju i unapređenju relevantnih faktora od presudnog je značaja za dostizanje i očuvanje željenog nivoa kvaliteta. Ovaj rad ima za cilj da ispita nivo inovativnosti restorana u Vojvodini s obzirom da imaju konkurentnu ponudu i na taj način ostvaruju povoljne dugoročne rezultate. Nivo inovacija određuje se na osnovu instrumenta za merenje inovacija u oblasti proizvoda i usluga, marketinga, procesa i društveno odgovornog ponašanja. Da bi se utvrdio stepen inovativnosti, potrebno je da se prvo utvrdi procenat inovativnosti na osnovu broja inovacija koje su uveli restorani u sve četiri posmatrane oblasti.

Rezultati istraživanja pokazuju da veliki broj restorana obraća pažnju na inovacije sa ciljem da privuku što veći broj gostiju i unaprede sveukupni učinak. S druge strane, više od polovine posmatranih restorana ima veoma nizak ili nizak stepen inovativnosti, što ukazuje na to da još uvek ne posvećuju dovoljno pažnje inovacijama i unapređenju njihove primene u svakodnevnom poslovanju.

\section{Ključne reči:}

inovacije u restoraterstvu, gastronomski trendovi, marketinške inovacije u restoraterstvu, inovacije usluga. 